\title{
EFFECT OF UV-C TREATMENT ON MICROBIAL POPULATION AND BIOACTIVE COMPOUNDS OF ORANGE JUICE USING MODIFIED REACTOR BASED ON DEAN VORTEX FLOW
}

\author{
S1la Barut Gök ${ }^{*}$ \\ Department of Food Technology, Çorlu Vocational School, Tekirdağ Namık Kemal University, Tekirdağ, \\ Turkey
}

Received / Geliş: 24.02.2021; Accepted / Kabul: 05.04.2021; Published online / Online bask1: 19.04.2021

Barut Gök, S. (2021). Effect of UV-C treatment on microbial population and bioactive compounds of orange juice using modified reactor based on dean vortex flow. GIDA (2021) 46(3) 634-646 doi: 10.15237/gida.GD21042

Barut Gök, S. (2021). Dean girdabı akışına dayalı reaktör tasarımı ile UV-C uygulamasının portakal suyunun mikrobiyal yükü ve biyoaktif bileşenlerine etkisi. GIDA (2021) 46(3) 634-646 doi: 10.15237 /gida.GD21042

\begin{abstract}
The aim of the present study was to investigate the effectiveness of UV-C treatment using a modified UV$\mathrm{C}$ reactor based on Dean vortex flow. Parameters taken into account were total aerobic bacteria count and yeast and mould counts, antioxidant capacity, total phenolic content, 5-HMF content, furan formation and sensory attributes. A UV-C treatment with $68.75 \mathrm{~mJ} / \mathrm{cm}^{2}$ led to $2.21-\log \mathrm{CFU} / \mathrm{ml}$ and $1.13-\log \mathrm{CFU} / \mathrm{ml}$ reduction of TMAB and YM count, respectively. DPPH radical scavenging activity and total phenolic content of UV-C treated orange juice significantly decreased. However, UV-C induced reduction of HMF was observed. UV-C treatment would be a beneficial method to eliminate or decrease the HMF content if HMF were present in the juice as a consequences of obtained results. $\mathrm{pH}$ and ${ }^{\circ}$ Brix remained constant after UV-C treatment. No furan formation was detected and no significant change observed in the quality attributes in regards to appearance and colour.

Keywords: Ultraviolet (UV) radiation; dean flow; bioactive compounds; microbial inactivation; antioxidant activity; 5-HMF; sensory evaluation

\section{DEAN GİRDABI AKIŞINA DAYALI REAKTÖR TASARIMI İLE UV-C UYGULAMASININ PORTAKAL SUYUNUN MİKROBİYAL YÜKÜ VE BIYYOAKTİF BİLEŞENLERİNE ETKİSİ}

\section{ÖZ}

Bu çalışmanın amacı, Dean girdabı akışına dayalı tasarlanan UV-C reaktör ile UV-C ışınlama işleminin etkinliğinin araştırılmasıdır. Çalışmada kullanılacak parametreler toplam aerobik bakteri sayısı ile maya ve küf sayısı, antioksidan kapasite, toplam fenolik madde miktarı, 5-HMF içeriği ile furan oluşumu ve duyusal özellikler olarak belirlenmiştir. $68,75 \mathrm{~mJ} / \mathrm{cm}^{2} \mathrm{UV}-\mathrm{C}$ 1şın uygulaması toplam mezofilik aerobik bakteri ve küf-maya sayısında sirasiyla 2,21-log CFU/ml ve 1,13-log CFU/ml azalmaya neden olmuştur. UV-C ile muamele edilmiş portakal suyunun DPPH radikal temizleme aktivitesi ve toplam fenolik içeriği önemli ölçüde azalmıştır. Bununla birlikte, UV-C ışınlama ile HMF miktarında azalma saptanmıştır. Elde edilen sonuca göre, HMF içeren meyve sularında UV-C uygulaması, HMF içeriğini ortadan kaldırmak veya azaltmak için faydalı bir yöntem olacaktır. $\mathrm{pH}$ ve ${ }^{\circ}$ Brix değerleri, UV-C

${ }^{*}$ Corresponding author / Yazışmalardan sorumlu yazar

凶sbgok@nku.edu.tr, @ (+90) 2822503512

且 $(+90) 2822509939$

Sıla Barut Gök; ORCID no: 0000-0001-7666-9630 
işleminden sonra değişmemiştir. İşlem sonrasında, furan oluşumu tespit edilmemiş, görünüş ve renk açısından kalite özelliklerinde önemli bir değişiklik saptanmamışur.

Anahtar kelimeler: Ultraviyole (UV) 1şın; dean akışı; biyoaktif bileşenler; mikrobiyal inaktivasyon; antioksidan aktivite; 5-HMF; duyusal değerlendirme

\section{INTRODUCTION}

Fruit juices are perceived as healthy foods by consumers to meet their nutritional requirement particularly in terms of micronutrients (Nnam and Njoku, 2005; Guerrouj et. al., 2016) and are among the fresh-like food products with the increasing consumer demand in nonthermal or minimal processing for preservation (Liang et al., 2006). However, fruit juice is vulnerable to degradation by heat, microorganism, enzymes, oxygen, and light during processing and storage (Liang et al., 2006). Fresh juices are spoiled with time due to the growth of microorganisms from all three morphological groups (i.e. moulds, yeasts and bacteria) (Splittstoesser, 1982; Trifirò et al., 1997). The most frequently found bacteria in orange juice are Lactobacillus, Leuconostoc and spore formers like Bacillus, Alicyclobacillus and Clostridium that could survive high temperatures and low $\mathrm{pH}$ values of fruit juices (Tran and Farid, 2004; Sadler et al., 1990; Kimball, 1991, Kimball, 1996). Therefore, juice should undergo commercial pasteurization to inactivate most of the microorganisms (Tran and Farid, 2004). However, the process tend to lose of its beneficial nutrients (Liang et al., 2006) such as vitamins (ascorbic acid) (Zerdin et al., 2003), phenolic acids and flavanones and organoleptic quality like colour, aromas (Choi and Nielsen, 2005). With the increasing consumer demand for fresh-like products such as fruit juice, there is a growing interest in non-thermal or minimal processing for food preservation. Among these methods, ultraviolet (UV) processing has gained attention in order to ensure safety and extend shelf life while minimizing negative effects on food quality attributes.

UV-C light has been used in the food industry for disinfection and decontamination treatments including water sterilization and waste water disinfection, decontamination of air in the meat and vegetable processing, surface and food packaging industry, reduction of pathogen microorganisms in red meat, poultry and fish processing (Unluturk et al., 2008). UV-C light in the wavelength of $253.7 \mathrm{~nm}$ could be efficiently absorbed by the DNA (Hoyer, 1998), and inactivates most of the microorganisms (Allende et al., 2006), such as bacteria, moulds, yeasts and viruses (Price, 1965; Unluturk et al., 2008; Gabriel and Nakano, 2009; Barut Gök and Pazır, 2020).

The design of an efficient UV-C reactor made to reduce pertinent microorganisms and comply with current food safety goals is still an engineering challenge (Barut Gök et al., 2021). Compared to water, liquids have a broad range of optical and physical properties that influence UV$\mathrm{C}$ light transmittance, dose delivery, and consequently microbial inactivation (Abdul Karim Shah et al., 2016). Some properties (absorbance/optical density, turbidity etc.) of the liquid being processed is one of the most important criteria to bear in mind when designing a UV-reactor.

In this study, a previously designed UV-C reactor (Barut Gök, 2018) which was purposed to eliminate some drawbacks of existing reactors like low penetration of UV-C energy and improve the energy transferred into the liquid by the flow characteristic based on the Dean vortex flow (Dean, 1927), was used to inactivate the aerobic bacteria count and yeasts and moulds count in orange juice. Furthermore, the effect of UV-C light on antioxidant activity, total phenolic content, 5-HMF and furan content and sensorial attributes were evaluated.

\section{MATERIAL AND METHOD}

\section{Analytical determinations}

The physical and physicochemical properties of orange juice was determined at $20^{\circ} \mathrm{C} \pm 1{ }^{\circ} \mathrm{C}$. The absorbance value of the orange juice was measured using a spectrophotometer (UVMini1240, Shimadzu, Japan) at $254 \mathrm{~nm}$ wavelength. Absorbance coefficient $\left(A_{e}\right)$ was estimated from the slope of absorbance versus sample concentration plot with different dilution 
factors. The amount of total soluble solids was determined using a refractometer (Hannah, USA) and was given in ${ }^{\circ} \mathrm{Bx}$ (Brix). The viscosity of the fruit juices was measured using a viscometer (SV10 Series, A\&D, Japan). $\mathrm{pH}$ values were determined using $\mathrm{pH} / \mathrm{mV}$ Meter (Hannah, Hi, 2211-02, USA). The titration acidity was determined by applying titration with $0.1 \mathrm{~N}$ $\mathrm{NaOH}$ to a $\mathrm{pH}$ end-point of 8.1 using $\mathrm{pH} / \mathrm{mV}$ Meter (Hannah, Hi, 2211-02, USA), and the results were expressed as gram of citric acid per liter of orange (g CA/L) (AOAC, 1995). The characteristics of orange juice are given in Table 1.

Table 1 Some product characteristics of orange juice. The standard deviation is indicated $(n=3)$.

\begin{tabular}{cc}
\hline Name & OJ \\
\hline Absorption coefficient $\left(\mathrm{cm}^{-1}\right)$ & 28.38 \\
$\mathrm{pH}$ & $4.00 \pm 0.01$ \\
Viscosity (mPa s) & $2.42 \pm 0.01$ \\
Soluble solids ( ${ }^{\circ}$ Brix $)$ & $12.00 \pm 0.9$ \\
$\mathrm{TA}^{*}$ & $0.82 \pm 0.003$
\end{tabular}

TA, titratable acidity, OJ, freshly squeezed orange juice * gram citric acid/100 ml (orange juice)

\section{Reflective flow-path UV-C reactor design and Dean Vortex}

The UV-C reactor design which has a reflective flow-path consist of a low-pressure mercury lamp (TUV 75W HO UVC, Philips Co., the Netherlands) of $75 \mathrm{~W}$ (28.1 W UV-C output), emitting radiation peak at $254 \mathrm{~nm}$. Flow occurs in an annular gap of approx. $3 \mathrm{~mm}$ through a length of approx. $60.1 \mathrm{~cm}$ between stainless steel wall and a sleeve made from quartz glass (Fig 1). Quartz glass sleeve positioned around the UV lamp that was located in the centre of the reactor (Barut Gök, 2018; Barut Gök, 2021). A peristaltic pump adjusted the flow rate through the reactor.

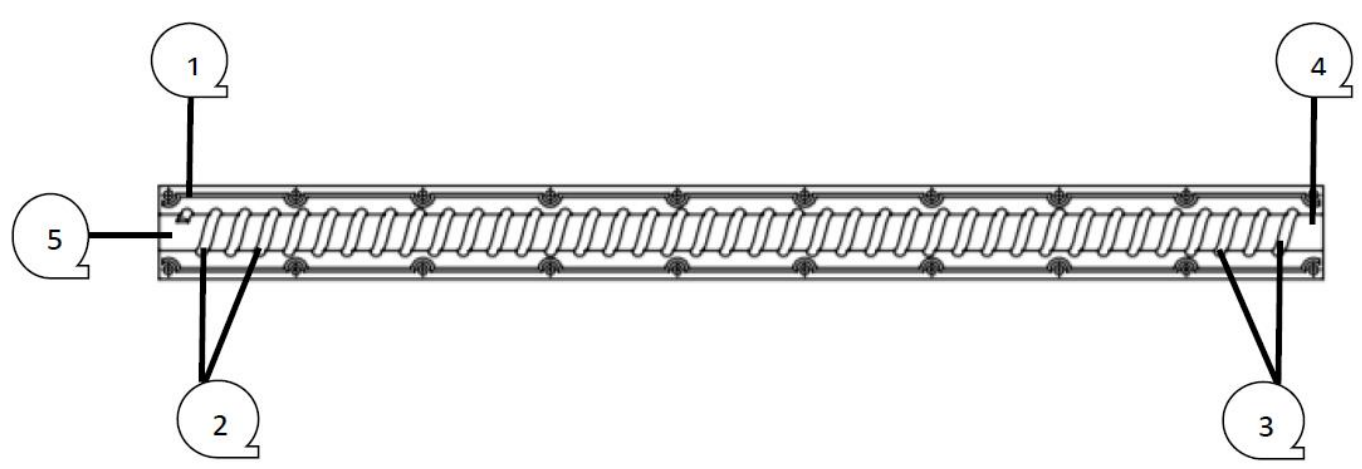

Figure 1. UV-C reactor design

The flow profile of a liquid inside a curved pipe is known as "Dean flow" and a secondary flow area is accompanied by the laminar fluid flow in the pipe due to a pressure drop caused by centrifugal forces acting in the fluid. In Dean flow based-UV reactors, the secondary flow vortices enable the irregular mixing of liquid particles (Koutchma et al., 2007). Therefore, even in cloudy juices with low UV-penetration depths, all fluid elements could be treated (Franz et al., 2009). The fluid is therefore assumed to be ideally mixed by the effect of the dean vortices throughout the pipe. The motion of the fluid in vortexes allows the fluid to be exposed closer to the UV-C source. In 
addition to this, vortices have more uniform velocity profile and narrower residence time distributions are procured (Dean, 1927).

Dean number $(D e)$ was calculated using the following equation (1) based on the geometric data of the helical flow channel and Reynolds number ( $R e$ ) (Ko and Ting 2006) for "Dean flow". In this equation, $r_{o}(\mathrm{~m})$ is the radius of the flow channel, and a $(\mathrm{m})$ is the radius of the curvature of the flow channel in the spiral structure. The calculation of the dimensionless $R e$, which is both used in calculating the $D e$ and determining the flow regime, is given in equation (2) (Geankoplis 2003). In the equation (2), the diameter $(D, \mathrm{~m})$ of the flow channel corresponds to $6 \mathrm{~mm}$ and $u(\mathrm{~m} / \mathrm{s})$ is the flow rate, $\varrho\left(\mathrm{kg} / \mathrm{m}^{3}\right)$ is the density of the fluid and $\mu(\mathrm{Pas})$ is the viscosity of the fluid.

$D_{e}=\operatorname{Re} \sqrt{\left(r_{o} / a\right)}$

$R e=\frac{D \times v \times \rho}{\mu}$

$R e$ for orange juice was calculated for flow rate of $2.1 \pm 0.1 \mathrm{~L} / \mathrm{h}$ that was determined in preexperiments. The flow regime of both juices was laminar $(\operatorname{Re}<2100)$. The $R e$ numbers were calculated in light of the geometrical data of the helical coiled flow channel as 123 and 35 is the De numbers consisted during the flow in the UV-C reactor for orange juice.

\section{UV-C dosimetry}

The UV dose (D) is obtained as the multiplication of the irradiation time $(t)$ and the UV radiation intensity $\left(I_{\text {avg }}\right)$, as given in equation 4 .

UV-C intensity was measured using an UVradiometer (UVP, USA). The average intensity $\left(I_{\text {avg }}\right)$ was calculated according to the BeerLambert law's integration, as given by equation (3) by using the incident intensity measured by the UV-C sensor $\left(I_{0}\right)$ (Unluturk et al., 2008) in order to add the losses due to absorption into calculation. $I_{o}$ was measured as $22.3 \mathrm{~mW} / \mathrm{cm}^{2}$ at the surface of quartz glass where is the shrink-fit point between quartz and the flow channel. In the equation, $A_{e}$ shows the absorption coefficient
$(1 / \mathrm{cm})$ and $L$ is the path length $(\mathrm{cm})$ of the cuvette. The absorbance values of fruit juices were measured at $254 \mathrm{~nm}$ wavelength in the spectrophotometer. Different dilution factors $(1: 10,1: 25,1: 50,1: 100,1: 1000)$ were used for orange juice and $A_{e}$ was estimated from the slope of the curve of the absorbance versus dilution factor. $68.75 \mathrm{~mJ} / \mathrm{cm}^{2}$ of UV-C doses were calculated for freshly squeezed orange juice.

$I_{\text {avg }}\left(\mathrm{mW} / \mathrm{cm}^{2}\right)=I_{o} \times\left(1-\exp \left(-A_{e} \times L\right)\right) /\left(A_{e} \times L\right)$

$D=I_{\text {avg }} \times t$

\section{Fruit Juice}

Freshly squeezed orange juice was used in this study. Freshly squeezed orange juice (OJ) was analysed for microbiological analysis, antioxidant activity, total phenolic content, 5-HMF, pH, Brix, titratable acidity and sensory analysis in order to observe the effect of UV-C light on physicochemical properties and formation of 5HMF and furan. Fresh orange juice was manufactured from oranges purchased in a local supermarket the day before juicing and stored at $4 \pm 0.1^{\circ} \mathrm{C}$ until juice extraction. Orange juice was obtained using a household juicer (Arzum Co., Model No. AR 164 Mela Plus, Turkey) and then filtered and then poured into the sterile bottles prior to processing.

\section{Microbiological analysis}

The microbial load was analysed by using $10 \mathrm{ml}$ of orange juice and mixing it with $90 \mathrm{~mL}$ of sterile $0.1 \%$ peptone water. Tenfold dilution series were made in sterile $0.1 \%$ peptone water. Plate Count Agar (Merck, Germany) for total aerobic bacteria (TAB) and Potato Dextrose Agar (Merck, Germany) for yeast-mould (YM) counts were pour plated and incubated at $30{ }^{\circ} \mathrm{C}$ for $48 \mathrm{~h}$ (Harrigan and McCance 1976) and $25^{\circ} \mathrm{C}$ for 5 days (Anonymous 2001), respectively. YM counts were enumerated together in the same medium. All microbiological analyses were performed in parallel and in triplicates. Results are given in colony forming units per milliliter $(\mathrm{CFU} / \mathrm{ml})$. 


\section{Determination of antioxidant capacity by DPPH radical scavenging method}

Antioxidant activities of orange juices were determined according to (Brand-Williams et al., 1995). Different concentrations of orange juices were taken into tubes and $600 \mu \mathrm{l}$ of molar $\mathrm{DPPH}^{*}$ radical solutions were added on it and in each tube, the total volume was completed to $6 \mathrm{ml}$ with methanol. After mixing and incubating the tubes for $30 \mathrm{~min}$, at room temperature and dark medium, absorbance was read at $517 \mathrm{~nm}$ wavelength against the control. By using the absorbance value, the $\%$ inhibition of DPPH radicals (I \%) for each of the samples was calculated by using the equation (5). In equation (5), the absorption of control (methanol instead of fruit juice) was expressed as $A_{\text {control }}$ and the absorption of the sample taken into analysis was expressed as $A_{\text {sample. }}$

Inhibition $\%=\left(\left(A_{\text {control }}-A_{\text {sample }}\right) /\left(A_{\text {control }}\right)\right) \times 100$

Inhibition values were graphed versus different concentrations of each juice and linear regression analysis was applied in order to obtain the equation defining the curve. By using the equation, the $\mathrm{EC}_{50}$ value was calculated.

\section{Determination of the total phenolic material content}

The determination of phenolic compounds, as stated (Franke et al., 2004), was carried out according to the proposed method by modifying the method based on the reaction occurred between phenolic compounds of juice and FolinCiocalteu reagent. The absorption of the bluecoloured solution after an incubation time of 60 min was read at $720 \mathrm{~nm}$ wavelength and evaluated with the standard curve of Gallic acid (Singleton, 1985). The results were given as $\mathrm{mg}$ gallic acid equivalent/L (mg GAE/L).

\section{Determination of 5-HMF and furan formation}

The determination of 5-bydroxymetbylfurfural in orange juice was carried out quantitatively, following the procedure described by the IFFJP (1985) based on the colorimetric reaction between barbituric acid, p-toluidine and HMF, forming a red-coloured complex. The intensity of red colour is dependent upon the concentration of HMF, which was measured at $550 \mathrm{~nm}$ using spectrophotometer. $20 \mathrm{ml}$ of juice was measured by using a measuring cylinder and transfer to a $100 \mathrm{ml}$ volumetric flask. The rest of the volume was completed with deionized water and was shaken well. $2.0 \mathrm{ml}$ of the diluted sample solution was pipetted to each of two tubes and $5.0 \mathrm{ml} \mathrm{p}$ toluidine solution was added to both. All tubes were shaken well. $1.0 \mathrm{ml}$ of water was added to one tube (blank value) and $1.0 \mathrm{ml}$ of barbituric acid solution to the other with gentle shaking. Analysis was completed without delay and in 1-2 minutes. The absorbance of the sample against the blank was measured as soon as the colour intensity has reached a maximum (3-4 minutes after adding the barbituric acid solution), using 1 $\mathrm{cm}$ cells at $550 \mathrm{~nm}$. The content of HMF is calculated as follows equation (6) (VdF, 1987; Başkaya Sezer et al., 2016).

$H M F, m g / L=162 \times(A)$

Automated headspace sampling followed by Gas chromatography/mass spectrometry (GC/MS) analysis was used to detect furan formation. Samples were analysed for furan content on a GC/MS (GC-MS, Hewlett Packard 6890). An HP-5MS column (coated with (5\%-phenyl)methylpolysiloxane phase) (dimensions: $30 \mathrm{~m}$ $0.25 \mathrm{~mm}$, film thickness: $0.25 \mathrm{um}$ ) was used for the analysis. Helium was used as carrier gas at a flow rate of $1.7 \mathrm{ml} / \mathrm{min}$ (constant flow). The oven temperature was programmed from $50{ }^{\circ} \mathrm{C}(1$ min), $10{ }^{\circ} \mathrm{C} / \mathrm{min}$ ramp rate to $225^{\circ} \mathrm{C}$, and then hold for $12.5 \mathrm{~min}$. The total run time for each sample was $30 \mathrm{~min}$. The samples were injected with a splitting 2:1. The ionisation mode was electron ionisation $(70 \mathrm{eV})$. Detection was in selected ion monitoring (SIM) mode, using three characteristic ions for furan ( $\mathrm{m} / \mathrm{z} 68$ as target ion, and $\mathrm{m} / \mathrm{z} 37$ and $\mathrm{m} / \mathrm{z} 39$ as qualifiers). The injector temperature was $230{ }^{\circ} \mathrm{C}$. Mass range was from $\mathrm{m} / \mathrm{z} 25$ to 150 . For the SPME automated method, vials with $20 \mathrm{ml}$ headspace were placed on a head space autosampler (HP 7694A Headspace Autosampler) and samples were equilibrated for $30 \mathrm{~min}$. Analysis of furan was carried out using a modified US FDA (2004) method. The furan stock standard was prepared by transferring $50 \mu \mathrm{L}$ 
of furan through the septum of the headspace vial containing $20.0 \mathrm{~mL}$ methanol $(2.5 \mathrm{mg} / \mathrm{ml})$. The working standard was prepared by transferring $250 \mu \mathrm{L}$ of the $c a .2 .50 \mathrm{mg} / \mathrm{ml}$ furan stock standard to a sealed headspace vial containing $20 \mathrm{~mL}$ water.
The calibration curve was prepared by plotting response ratio and ratio of amounts of furan (Fig 2). The sample exposed to UV radiation was diluted suitably by transferring $5 \mathrm{ml}$ juice sample into the headspace vial and adding $5 \mathrm{ml}$ water.

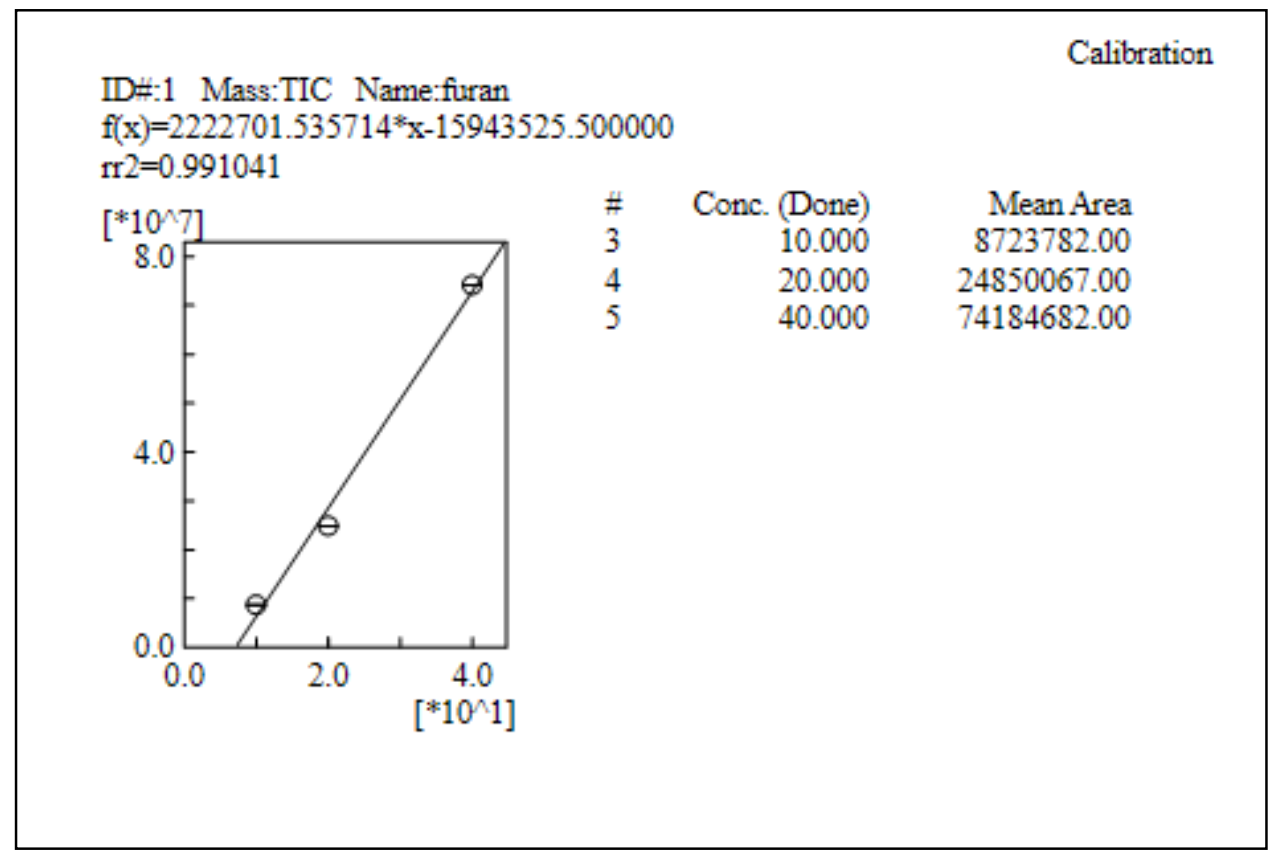

Figure 2. Furan calibration curve

\section{Sensory analysis}

Six panellists were selected and trained for the sensorial panel. Samples of $25 \mathrm{ml}$ were coded with 3 -digit numbers and presented to the panellists in random order in transparent cups. The overall acceptability of the juices was carried out by adopting the classic standard scoring test (Altug and Elmac1, 2005; Oras et al. 2017). The overall sensory acceptability of the treated juice was evaluated using certain parameters, such as appearance, colour, odour and taste, each on a 5point scale ranging from 1 (dislike extremely) to 5 (like extremely) (Watts, 1989). The sensory test was replicated three times.

\section{Statistical analysis}

The generated results are averages of at least three measurements. The results were analysed for mean values and standard deviations. Also, univariate analysis of variance and the Duncan post hoc test by SPSS (Version 16.0, SPSS Inc., IL, USA) were applied to statistically analyse and evaluate (5\% levels). Evaluation of sensory analysis was done by analysis of variance according to Altuğ and Elmacı (2005).

\section{RESULTS AND DISCUSSION}

\section{UV-C inactivation of microorganisms}

The results of total mesophilic aerobic bacteria (TMAB) and yeast-mould (YM) counts are summarized in Table 2. The initial number of TMAB and YM counts were determined as $3.3 \times 10^{4}$ and $1.2 \times 10^{5} \mathrm{CFU} / \mathrm{ml}$ for orange juice, respectively. Orange juice received UV dosage level of $68.75 \mathrm{~mJ} / \mathrm{cm}^{2}$, and resulted in a $2.21-\log$ $\mathrm{CFU} / \mathrm{ml}$ and $1.13-\log \mathrm{CFU} / \mathrm{ml}$ reduction of TMAB and YM count, respectively. There were statistically significant difference in the inactivation efficiency of UV-C radiation on total mesophilic aerobic bacteria and yeast-mould count compared to untreated samples $(P>0.05)$. It was reported that a $1377 \mathrm{~J} / \mathrm{mL}$ of UV-C treatment of orange juice resulted in 0.90 and $0.30-\log$ $\mathrm{CFU} / \mathrm{mL}$ reductions in total aerobes and yeast- 
mould count, respectively (Keyser et al., 2008). In addition to this, a $37.5 \mathrm{~J} / \mathrm{mL} \mathrm{UV-C}$ treatment of watermelon juice resulted in 1.47 and $0.99-\log$ $\mathrm{CFU} / \mathrm{ml}$ reductions in total aerobes and yeastmould counts, respectively while a $2.7 \mathrm{~J} / \mathrm{mL} \mathrm{UV}$ $\mathrm{C}$ dose is resulted in 0.60 and $0.53-\log \mathrm{CFU} / \mathrm{mL}$ reductions in total aerobes and yeast-mould (Feng et al., 2013). It was also reported that the reason for this relatively low reduction in bacterial numbers can be attributed to the cells and other particles like fibre present in the orange juice, which could act as a barrier between the UV-C rays and the bacteria (Keyser et al., 2008). In this study, the relatively high inactivation rates could be due to the Dean effect which enables the secondary flow vortices acting in the fluid. However, previous study performed in the same reactor, the reduction in total mesophilic aerobic bacteria and yeast-mould counts of white grape juice were $5.42-\log \mathrm{CFU} / \mathrm{mL}$ and $4.86-\mathrm{log}$ $\mathrm{CFU} / \mathrm{mL}$ at the UV-C dose of $280 \mathrm{~mJ} / \mathrm{cm}^{2}$, respectively (Barut Gök, 2018). The reason for the relatively low reduction rates in microbial load of orange juice compared to grape juice could be attributed to the cells and fibre present in orange juice (Keyser et al. 2008).

Table 2 Effect of UV-C treatment on microbial load of orange juice. The standard deviation is indicated.

\begin{tabular}{c|cc}
\hline & \multicolumn{2}{|c}{ Orange juice } \\
\hline $\begin{array}{c}\text { Microbial Load } \\
(\text { log CFU/ml })\end{array}$ & \multicolumn{2}{|c}{$\begin{array}{c}\text { UV-C dose } \\
\left(\mathrm{mJ} / \mathrm{cm}^{2}\right)\end{array}$} \\
\hline TMAB* $^{*}$ & 0 & 68.75 \\
\hline Yeast-mould count & $4.50 \pm 0.06^{\mathrm{a}}$ & $2.30 \pm 0.05^{\mathrm{b}}$ \\
\hline
\end{tabular}

a,b, Different letters in each row indicate significant difference at $(\mathrm{p}<0.05)$ (Duncan test). The freshly squeezed orange juice was evaluated among the treatment.

*TMAB, total mesophilic aerobic bacteria

\section{Antioxidant capacity}

The changes in antioxidant capacity after processing with UV-C are shown in Table 3. A significant difference was detected in the antioxidant capacities of orange juice samples between the UV-C treated and untreated. UV-C treated sample showed significant increase in the $\mathrm{EC}_{50}$ value compared to control indicating a lower level of antioxidants. The percent decrease of antioxidant capacity was $32.6 \%$ at the UV-C dose of $68.75 \mathrm{~mJ} / \mathrm{cm}^{2}$. Different reports concerning the effects of the UV dosage on the antioxidant capacity of fruit juices are available.

Similar results to our study were proved by UV-C treatment of apple juice at the doses of $20 \mathrm{~mJ} / \mathrm{cm}^{2}$ to $140 \mathrm{~mJ} / \mathrm{cm}^{2}$ (Islam et al. 2016). UV-C treatment could either enhance or decrease the antioxidants, which are entirely dependent on the exposure time, delivered dose, extraction solvents used and the basic raw material (Alothman et al., 2009). Bhat et al. (2011) reported that a non- significant increase in the antioxidant capacity of star fruit juice after a UV-C dose of $2.158 \mathrm{~J} / \mathrm{m}^{2}$. Caminiti et al. (2011) found that non-significant decrease in antioxidant capacity of apple and cranberry juice after a dose of $5.3 \mathrm{~J} / \mathrm{cm}^{2}$. It has been reported that a non-significant change in the antioxidant capacity of UV-C treated (0.56-13.62 $\mathrm{kJ} / \mathrm{m}^{2}$ ) pomegranate arils (Lopez-Rubira et al., $2005)$ and UV-C treated $\left(4.0 \mathrm{~kJ} / \mathrm{m}^{2}\right)$ carrots (Formica-Oliveira et al., 2017). Although the knowledge about which mechanisms or parameters of UV-C treatment influence the antioxidant capacity, the actual biochemical mechanism causing an increase or decrease in the antioxidant capacity of irradiated product is still obscure.

\section{Total phenolic content (TPC)}

Orange juice showed an initial total phenolic content (TPC) of 1909 $\pm 0.01 \mathrm{mg}$ GAE/L (Table 3). As expected, UV-C treatment has a significant 
effect on the TPC as similarly observed for antioxidant capacity. The content of total phenolic compounds in the freshly squeezed orange juice was higher than that of the UV-C treated one. Different results concerning the effect of UV-C on the TPC of different samples have been reported. It has been reported that different UV-C intensities had no significant effect on phenolic compounds of watermelon juice (Feng et al., 2013), apple juice (Caminiti et al., 2011) and pomegranate juice (Pala and Toklucu, 2011), in comparison to untreated juice samples. Similar to the results of current study, Noci et al. (2008) reported a significant decrease in total phenolic compounds, compared to fresh juice. The reduction in the phenolic content could be due to the degradation, oxidation, or polymerization of phenolic compounds quickly during processing of juice (Feng et al., 2013).

Table 3 Effect of UV-C light on antioxidant activity, total phenols, 5-HMF content, brix, $\mathrm{pH}$ and TA values of orange juice. The standard deviation is indicated $(n=3)$.

\begin{tabular}{|c|c|c|}
\hline & \multicolumn{2}{|c|}{ Orange juice } \\
\hline & 0 (control) & $\begin{array}{l}\text { UV-C dose } \\
68.75 \mathrm{~mJ} / \mathrm{cm}^{2}\end{array}$ \\
\hline $\begin{array}{c}\mathrm{EC}_{50}{ }^{* *} \\
(\mu \mathrm{l} \text { fruit juice })\end{array}$ & $3.59 \pm 0.03^{\mathrm{a}}$ & $4.76 \pm 0.02^{b}$ \\
\hline $\begin{array}{l}\text { Total phenols } \\
\text { (mg GAE/L) }\end{array}$ & $1909 \pm 0.01^{\text {a }}$ & $1447 \pm 0.01^{b}$ \\
\hline 5-HMF mg/L & $196 \pm 1.53$ a & $175 \pm 1.53 \mathrm{~b}$ \\
\hline${ }^{\circ}$ Brix & $12.00 \pm 0.9$ ns & $12 \pm 0.9 \mathrm{~ns}$ \\
\hline $\mathrm{pH}$ & $4.00 \pm 0.01^{\mathrm{ns}}$ & $3.97 \pm 0.01 \mathrm{~ns}$ \\
\hline TA*** & $0.82 \pm \pm 0.02 a$ & $0.68 \pm 0.03 \mathrm{~b}$ \\
\hline
\end{tabular}

a,b Different letters in each row indicate significant difference at $(\mathrm{p}<0.05)$ (Duncan test). The freshly squeezed orange juice was evaluated among the treatment.

ns Not significant.

** Concentration of sample necessary to reduce by $50 \%$ the inhibition of free radical scavenging.

*** Gram citric acid/100 ml (OJ); NA, not detected

\section{5-HMF content and furan formation}

5-hidroxymethylfurfural (HMF) is formed in the Maillard reaction as well as during caramelization as the result of hexose dehydration under hightemperature environments or acidic conditions (Aguilar et al. 2016) such as fruit juices and syrups. High 5-HMF content in these products are associated with low quality (Ros-Polski et al., 2016) since high values reveal an excessive thermal treatment, inappropriate storage conditions (Aguilar et al., 2016). It would be beneficial to reduce the content or to prevent the formation of HMF which is declared as "possibly carcinogenic to humans" by The International Agency of Research on Cancer (IARC 1995). 5HMF content is represented in Table 3 . The present study showed that HMF formation did not occur immediately after the UV-C treatment.
In addition to this, the HMF content decreased after UV-C treatment. Similar results to current study it has been reported that if HMF were present in the juice, UV-C treatment would be a beneficial method to eliminate or decrease it. Moreover, HMF could be degraded by UV light regardless the initial concentration of it (Aguilar et al. 2016). UV-C induced reduction of HMF was previously observed in high fructose corn syrup and model syrups. The reduction mechanisms was explained by reversing unwanted caramelisation-induced changes to colour and flavour (Ros-Polski et al., 2016).

The primary source of furan and its derivatives in foods is believed to be from the thermal degradation of carbohydrates such as glucose, lactose, and fructose (Ros-Polski et al., 2016). In 
addition to this, furan formation could occur nonthermal processing such as UV-C treatment (Fan and Geveke 2007). In this research no furan formation was detected in untreated and UV-C treated orange juice. These results are in agreement with the results of Fan (2005) where no furan was detected in apple cider exposed to a UV-C dose of $1.8 \mathrm{~J} / \mathrm{cm}^{2}$ and exposure times between 5 and 30 min of UV-C (Bule et al., 2010). Moreover, Bule et al. (2010) reported no furan formation up to $15 \mathrm{~min}$ of UV-C treatment in apple juice, too. Furan formation occurred after $15 \mathrm{~min}$ in apple juice. Furan generation in juices and beverages exposed to UV-C light is a complex process (Bule et al., 2010) and could be dependent on not only the matrix of product but also the dose applied.

\section{$\mathrm{pH}$, total soluble solids ( $\left.{ }^{\circ} \mathrm{Brix}\right)$ and titratable acidity (TA)}

The effect of the UV-C treatment on $\mathrm{pH}$, total soluble solids and titratable acidity are shown in Table 3. The UV-C treatment had no effect $(P<0.05)$ on parameters such as orange juice $\mathrm{pH}$ and total soluble solid content in both the fresh and UV-C treated juice. The fresh juice showed higher acidity than that of the UV-C treated ones. Similarly, exposure to UV light did not modify the original values of $\mathrm{pH}$ and ${ }^{\circ} \mathrm{Brix}$ of the orange and carrot juice blend (Caminiti et al., 2012), carrot juice (Riganakos et al., 2017), orange juice (Tran and Farid, 2004), white and red grape juices (Pala and Toklucu, 2013), apple juice (Caminiti et al., 2011; Falguera et al., 2011) and grapes (Pinto et al. 2016). Pala and Toklucu (2013) reported a nonsignificant decrease in white and red grape juices and apple juice.

\section{Sensory attributes of juice}

Additional analyses were performed to investigate the impact of UV-C light treatment on sensory properties of orange juice. The results of the sensory analysis are summarised in Table 4 . Appearance and colour scores resulted not significantly affected by UV-C treatment $(P>0.05)$. Jo and Lee (2012) reported that no differences among at different doses of UV treatments in terms of sensory preference test of carrot juice. Similarly, no significant effect of UV treatment on colour of orange juice (Tran and Farid, 2004) and fresh-cut melon cubes (Manzocco et al., 2011) were detected. Sensory evaluation showed that the UV-C treated orange juice had lower odour and taste scores as compared to the untreated ones. Similarly, it has been reported that, UV-C treated carrot juice resulted to be ranked second in preference in terms of odour and taste (Riganakos et al., 2017). This result is consistent with the reports of Matak et al. (2007) and Cilliers et al. (2014) where in decrease in flavour and aroma was observed in milk. In this case, a sufficient inactivation of PPO after UV-C treatment to maintain the colour in the juice could be the reason of remained colour as reported in apple juice (Müller et al. 2014) and white grape juice (Barut Gök, 2018). The nonsignificant effect of UV on colour of juice could also be explained by the minor effect of UV-C on nonenzymatic browning index that indicates the browning of juice (Koutchma et al., 2016). The off-flavour observed after UV-C treatment could be explained by damaging to vitamins, antioxidants and formation of undesirable components such as oxidation products.

Table 4 Appearance, colour, odour and taste scores of orange juice. The standard deviation is indicated $(n=3)$.

\begin{tabular}{c|cc}
\hline Quality attributes & \multicolumn{2}{|c}{ Orange juice } \\
\hline & 0 (control) & $\begin{array}{c}\text { UV-C dose } \\
68.75 \mathrm{~mJ} / \mathrm{cm}^{2}\end{array}$ \\
\hline Appearance & $4.7 \pm 0.5 \mathrm{~ns}$ & $4.5 \pm 0.8 \mathrm{~ns}$ \\
Colour & $4.7 \pm 0.5 \mathrm{~ns}$ & $4.7 \pm 0.8 \mathrm{~ns}$ \\
Odour & $3.6 \pm 0.9 \mathrm{a}$ & $2.4 \pm 0.9 \mathrm{~b}$ \\
Taste & $3.4 \pm 0.9^{\mathrm{a}}$ & $2.6 \pm 1.5^{\mathrm{b}}$ \\
\hline
\end{tabular}

a,b Different letters in each row indicate significant difference at $(\mathrm{p}<0.05)$ (Duncan test). The freshly squeezed orange juice was evaluated among the treatment.

ns Not significant. 


\section{CONCLUSION}

UV-C light is a non-thermal processing emerging technology for pasteurization of fruit juice. However, many difficulties such as absorbance and turbidity which depends on the characteristic of the liquid influence the efficiency of the UV-C light. This obstacle could be overcome by improving the reactor design in terms of changing the flow pattern. As it has been reported in the UV-C literature, a well-designed reactor that allows sufficient penetration of UV-C to liquids in a shorter time could be used to achieve microbiologically safe juices with minimal or no damage to bioactive components (Feng et al., 2013). In this study, by improving the flow channel of UV-C reactor it was aimed to not only improve the microbial efficiency of UV-C light but also minimize the degradation of bioactive compounds and formation of undesirable sensory consequences. It could be concluded that the designed reactor were effective in inactivating the microbial load in relatively low doses of UV-C compared to the results of juices in the literature which has been exposed higher doses. The results obtained in this study clearly indicated that the designed reactor has good potential to improve the microbiological quality of orange juice. However, further studies will be conducted to assess the efficiency of the reflective flow-path UV-C reactor design for the treatment of highly absorbing and scattering fluids or media. Although previous studies realised by the reactor occurred increase in bioactive compounds of apple, white and red grape juices it has been observed general reduction in antioxidant capacity and total phenolic in orange juice. This results showed that the designed reactor could be used in combination with other non-thermal preservation methods in order to prevent or decrease the loss of bioactive compounds from the point of view of orange juice. In addition to this, as has been previously suggested in the literature actual biochemical mechanism causing a degradation in the antioxidant capacity of irradiated product needs to be further studied. UV-C treatment in this research maintained the sensory attributes in terms of appearance and colour compared to fresh ones. As has been reported previous reviews very limited published researches are available in regards to effects of UV-C treatment on sensory attributes of juices. The study demonstrated that the UV-C light is a promising preservation method with keeping in mind that necessity of designing further studies in order to ascertain the exact parameters for each product.

\section{CONFLICT OF INTEREST}

The author expresses no conflict of interest associated with this work.

\section{REFERENCES}

Abdul Karim Shah, N.N.; Shamsudin, R.; Abdul Rahman, R.; Adzahan, N.M. (2016). Fruit juice production using ultraviolet pasteurization: a review. Beverages 2(3): 1-20.

Aguilar, K., Garvin, A., Ibarz, A. (2016). Effect of the concentration on the kinetic model of the photo-degradation of 5-hydroxymethylfurfural by UV irradiation. J Food Eng, 191: 67-76.

Allende, A., Tomas-Barberan, F.A., Gil, M.I. (2006). Minimal processing of healthy traditional foods. Trends Food Sci Technol, 17:513-519.

Alothman, M., Bhat, R., Karim, A.A. (2009). Effects of radiation processing on phytochemicals and antioxidants in plant produce. Trends Food Sci Technol, 20(5): 201-212.

Altug, T. Elmac1, Y. (2005). Gidalarda Duyusal Değerlendirme. Izmir: Meta Press, Turkey.

Anonymous (2001). Bacteriological analytical manual chapter 18 yeasts, molds and mycotoxins.

AOAC, 1995. Association of Official Analytical Chemists, Official methods of analysis (16 th $\mathrm{ed}$.), Washington, USA.

Barut Gök, S. (2021). UV-C treatment of apple and grape juices by modified UV-C reactor based on Dean vortex technology: Microbial, physicochemical and sensorial parameters evaluation. Food Bioprocess Technol, https://doi.org/10.1007/s11947-021-02624-z.

Barut Gök, S., Gräf, V., Stahl, M.R. (2021). Engineering Aspects of UV-C Processing for Liquid Foods, Editor(s): Kai Knoerzer, Kasiviswanathan Muthukumarappan, Innovative Food Processing 
Technologies, Elsevier, 2021, Pages 171-181, ISBN 9780128157824, https://doi.org/ 10.1016/B978-0-08-100596-5.23000-X.

Barut Gök, S., Pazır, F. (2020). Effect of treatments with UV-C light and electrolysed oxidizing water on decontamination and the quality of Gemlik black olives. J Consum Prot Food Saf, 15: 171-179. https://doi.org/10.1007/ s00003-019-01263-z.

Barut Gök, S. (2018). Usage of gamma irradiation $(\gamma)$ and ultraviolet (UV) radiaton in inactivation of the microorganisms of grape juice and the effects of operations on the quality of product. $\mathrm{PhD}$ Thesis. Tekirdağ Namı Kemal University Natural and Applied Science, Department of Food Engineering, Turkey, 255 p.

Başkaya Sezer, D., Erdoğan Tokatlı, K. Demirdöven, A. (2016). Bullace and Yonuz Plum Marmalades. JAFAG, 33 (1): 125-131.

Bhat, R., Ameran, S. B., Voon, H. C., Karim, A. A., Tze, L. M. (2011). Quality attributes of starfruit (Averrhoa carambola L.) juice treated with ultraviolet radiation. Food Chem, 127(2): 641644. doi:10.1016/j.foodchem.2011.01.042.

Bule, MV., Desai, KM., Parisi, B., Parulekar, SJ, Slade, P., Singhal, RS, Rodriguez, A. (2010). Furan formation during UV-treatment of fruit juices, Food Chem,122: 937-942.

Brand-Williams, W., Cuvelier, M. E., Berset, C. (1995). Use of a Free-Radical Method to Evaluate Antioxidant Activity. LWT-FOOD SCI TECHNOL, 28(1): 25-30.

Caminiti I.M., Noci, F., Morgan, D. J., Cronin, D. A., Lyng, J., G., (2012). The effect of pulsed electric fields, ultraviolet light or high intensity light pulses in combination with manothermosonication on selected physicochemical and sensory attributes of an orange and carrot juice blend. Food Bioprod Process, 90: 442448.

Caminiti, I. M., Noci, F., Munoz, A., Whyte, P., Morgan, D. J., Cronin, D. A., et al. (2011). Impact of selected combinations of non-thermal processing technologies on the quality of an apple and cranberry juice blend. Food Chem, 124(4): 1387-1392.

Cilliers, F. P., Gouws, P. A., Koutchma, T., Engelbrecht, Y., Adriaanse, C., Swart, P. (2014). A microbiological, biochemical and sensory characterisation of bovine milk treated by heat and ultraviolet (UV) light for manufacturing Cheddar cheese. IFSET, 23: 94-106.

Choi, L.H., Nielsen, S.S. (2005). The effect of thermal and non-thermal processing methods on apple cider quality and consumer acceptability. $J$. Food Qual, 28: 13-29.

Dean, W.R. (1927). Motion of fluid in a curved pipe. Philos Mag, p. 15.

Falguera, V., Pagan, J., Ibarz, A., (2011). Effect of UV irradiation on enzymatic activities and physicochemical properties of apple juices from different varieties. LWT-FOOD SCI TECHNOL, 44: 115-119.

Fan, X., (2005). Antioxidant capacity of fresh-cut vegetables exposed to ionizing radiation. J Sci Food Agric, 85(6): 995-1000.

Fan, X., Geveke, D. J., (2007). Furan formation in sugar solution and apple cider upon ultraviolet treatment. J Agric Food Chem, 55(19): 7816-7821.

Feng M., Ghafoor, K., Seo, B., Yang, K., Park, J., (2013). Effects of ultraviolet-C treatment in Teflon ${ }^{\circledR}$-coil on microbial populations and physico-chemical characteristics of watermelon juice. IFSET, 19: 133-139.

Franke, S. I. R., Ckless, K., Silveira, J. D., Rubensam, G., Brendel, M., Erdtmann, B., et al. (2004). Study of antioxidant and mutagenic activity of different orange juices. Food Chem, $88(1)$, 45-55. doi:10.1016/j.foodchem.2004.01.021.

Franz, C.M.A.P., Specht, I., Gyu-Sung, C., Graef, V., Stahl, M.R., (2009). UV-C inactivation of microorganisms in naturally cloudy apple juice using novel inactivation equipment based on Dean vortex technology. Food Control, 20: 11031107. 
Food and Drug Administration (2004). Exploratory data on furan in food data. US Food and Drug Administration.

Formica-Oliveira, A.C., Martinez-Hernandez, G. B., Diaz-Lopez, V., Artes, F., Artes-Hernandez, F., (2017). Effects of UV-B and UV-C combination on phenolic compounds biosynthesis in fresh-cut carrots. POSTHARVEST BIOL TEC, 127: 99-104.

Gabriel, A.A., Nakano, H., (2009). Inactivation of Salmonella, E. coli and Listeria monocytogenes in phosphate-buffered saline and apple juice by ultraviolet and heat treatments. Food Control 20: 443-446

Geankoplis, C.J. (2003). Transport processes and Unit OperationsTransport processes and Unit Operations. New Jersey: Prentice Hall.

Guerrouj, K. Sanchez-Rubio, M., TaboadaRodriguez, A., Cava-Rolla, R.M., Marin-Iniesta, F., (2016). Sonication at mild temperatures enhances bioactive compounds and microbiological quality of orange juice $F O O D$ BIOPROD PROCESS, 99: 20-28, 10.1016/j.fbp.2016.03.007

Harrigan, W.F., McCance, M.E., (1976). Laboratory methods in food and dairy microbiology. Academic Press, London.

Hoyer, O., (1998). Testing performance and monitoring of UV systems for drinking water disinfection. Water Supply, 16(1/2): 419-442.

IARC, International Agency for Research on Cancer (1995). Dry cleaning, some chlorinated solvents and other industrial chemicals. IARC Monographs on the Evaluation of Carcinogenic Risks to Humans, 63: 393-407.

IFFJP (1985). International federation of fruit juice producers (IFFJP) methods. Analysenanalysis. Zug. Switzerland: Fruit-Union Suisse Assoc. Suizzera Frutta.

Islam, M.S., Patras, A., Pokharel, B., Wu, Y., Vergne, M.J., Shade, L., Xiao, H., Sasges, M., (2016). UV-C irradiation as an alternative disinfection technique: Study of its effect on polyphenols and antioxidant activity of apple juice. IFSET, 34: 344-351.
Jo, C., Lee, K.H., (2012). Comparison of the efficacy of gamma and UV irradiation in sanitization of fresh carrot juice. Radiat Phys. Chem, 81: 1079-1081.

Keyser, M., Müller, I.A., Cilliers, F.P., Nel, W., Gouws, P.A., (2008).Ultraviolet radiation as a non-thermal treatment for the inactivation of microorganisms in fruit juice, IFSET, 9: 348-354.

Kimball, D. A., (1991). Citrus processing quality control and technology (pp. 117-126, 227-235). New York: Van Nostrand Reinhold.

Kimball, D. (1996). Oranges and tangerines. In L. P. Somogyi, D. M. Barrett, Y. H. Hui (Eds.), Processing Fruits: Science and Technology, major processed products, vol. 2 (pp. 265 - 304). USA, Western Hemisphere Technomic Publishing Company.

Ko, T. H., Ting, K. (2006). Optimal Reynolds number for the fully developed laminar forced convection in a helical coiled tube. Energy, 31(12), 2142-2152. doi:10.1016/j.energy.2005.09.001.

Koutchma, T., Popovic, V., Ros-Polski, V., Popielarz, A., (2016). Effects of Ultraviolet Light and High-Pressure Processing on Quality and Health-Related Constituents of Fresh Juice Products. COMPR REV FOOD SCI F, 15:844867.

Koutchma, T., Paris, B., Patazca, E., (2007). Validation of UV coiled tube reactor for fresh juices. J ENVIRON ENG SCI, 6(3):319-328. doi:10.1139/S06-058.

Liang, Z.W., Cheng, Z., Mittal, G.S., (2006). Inactivation of spoilage microorganisms in apple cider using a continuous flow pulsed electric field system. LWT-FOOD SCI TECHNOL, 39(4):351357. doi:10.1016/j.lwt.2005.02.019.

Lopez-Rubira, V., Conesa, A., Allende, A., Artes, F., (2005). Shelf life and overall quality of minimally processed pomegranate arils modified atmosphere packaged and treated with UV-C. POSTHARVEST BIOL TEC, 37:174-185.

Manzocco, L., Da Pieve, S., Maifreni, M., (2011). Impact of UV-C light on safety and quality of fresh-cut melon. IFSET, 12:13-17. 
Matak, K.E., Sumner, S.S., Duncan, S.E., Hoving, E., Worobo, R. W., Hackney, C.R., Pierson, M.D., (2007). Effects of ultraviolet irradiation on chemical and sensory properties of goat milk. $J$ Dairy Sci, 90(7): 3178-3186.

Müller, A., Noack, L., Greiner, R., Stahl, M. R., Posten, C., (2014). Effect of UV-C and UV-B treatment on polyphenol oxidase activity and shelf life of apple and grape juices. IFSET, 26:498-504.

Nnam, N.M., Njoku, I.E., (2005). Production and evaluation ofnutrient and sensory properties of juices made from citrusfruits. NigJ NutrSci, 26(2): 62-66.

Noci, F., Riener, J., Walking-Ribeiro, M., Cronin, D. A., Morgan, D. J., Lyng, J.G., (2008). Ultraviolet irradiation and pulsed electric fields (PEF) in a hurdle strategy for the preservation of fresh apple juice. J Food Eng, 85:141-146.

Oras, A., Akagic, A., Gasi, F., Spaho, N., Kurtovic, M., Meland, M., (2017). Sensory evaluation of blended cloudy apple juices. Works of the Faculty of Agriculture and Food Sciences, University of Sarajevo, 67: 493-504.

Pala, C.U., Toklucu, A.K., (2013). Effects of UVC Light Processing on Some Quality Characteristics of Grape Juices. Food Bioprocess Technol, 6: 719-725.

Pala, C.U., Toklucu, A.K., (2011). Effect of UV$\mathrm{C}$ light on anthocyanin content and other quality parameters of pomegranate juice. J Food Compos Anal, 24, 790-795.

Pinto, E.P., Perin, E. C., Schott, I. B., Rodrigues, R.S., Lucchetta, L., Manfroi, V., Rombaldi, C. V., (2016). The effect of postharvest application of UV-C radiation on the phenolic compounds of conventional and organic grapes (Vitis labrusca cv. Concord). POSTHARVEST BIOL TEC, 120: 84-91.

Price, W.C., (1965). Inactivation of southern bean mosaic virus by ultraviolet light. Virol J, 25:1-8.

Riganakos, K. A., Karabagias, I. K., Gertzou, I., Stahl, M., (2017). Comparison of UV-C and thermal treatments for the preservation of carrot juice. IFSET, 42: 165-172.

Ros-Polski, V., Popovic, V., Koutchma, T., (2016). Effect of ultraviolet-C light treatment on Hydroxymethylfurfural (5-HMF) content in high fructose corn syrup (HFCS) and model syrups. $J$ Food Eng, 179: 78-87.

Sadler G., Parish M., Davis J. (1990). Diacetyl Measurement in Orange Juice Using Differential Pulse Polarography, J Food Sci, (55)4: 1164 - 1165.

Singleton, V.L., (1985). Colorimetry of Total Phenolics with PhosphomolybdicPhosphotungstic Acid Reagents, The Curr Cont Agr Biol Envir Sci, 48: 18-18.

Splittstoesser, DF., (1982). Microorganisms Involved in the Spoilage of Fermented Fruit Juices. J Food Prot, 45(9):874-877. doi: 10.4315/0362-028X-45.9.874.

Tran, M.T.T., Farid, M., (2004). Ultraviolet treatment of orange juice, IFSET, 5: 495- 502.

Trifirò, A, Saccani, G, Gherardi, S, Vicini, E, Spotti, E, Previdi, MP, Ndagijimana, M, Cavalli S, Reschiotto C., (1997). Use of ion chromatography for monitoring microbial spoilage in the fruit juice industry. J Chromatogr A, 770:243-252.

Unluturk, S., Atilgan, M. R., Baysal, A. H., Tari, C., (2008). Use of UV-C radiation as a nonthermal process for liquid egg products (LEP). $J$ Food Eng, 85(4): 561-568. doi:10.1016/j.jfoodeng.2007.08.017.

Watts, B., (1989). Basic sensory methods for food evaluation, International Development Research Centre, Canada.

VdF (1987). RSK-Values. The Complete Manual.Verband der deutschen Fruchtsaffindustrie e.v. Bonn, Germany.

Zerdin, K., Rooney, M.L., Vermue, J., (2003). The vitamin $\mathrm{C}$ content of orange juice packed in an oxygen scavenger material. Food Chem, 82: 387395. 